\title{
Flow Injection Analysis of Chloride, Sulfate and Phosphate with a Displacement-Reaction Column
}

\author{
Akifumi YAMADA*, Kazunori HODOUCHI and Hiroshi MATSUBARA
}

Received February 10, 1993 ; Accepted March 30, 1993

\section{INTRODUCTION}

Flow injection analysis (FIA) has been widely used for the automation of chemical analysis. Many workers" have adapted a multi-manifold system for the determination of chloride, sulfate and phosphate; there are two or more pumps, flow streams and reaction coils in the system.

In this paper FIA combined with a single-line manifold and a new type of displacement-reaction column is described to analyze these anions; the samples react with the solid reagents in the reaction column according to a precipitation reaction. The apparatus is therefore very simple and the reagents can be easily exchanged. The usable working range of the method was extended to 0.01-3.1M $\left(\mathrm{M}=\mathrm{mol} \cdot \mathrm{dm}^{-3}\right)$ for $\mathrm{Cl}^{-}, 7 \times 10^{-5}-5 \times 10^{-1} \mathrm{M}$ for $\mathrm{SO}_{4}^{2-}$ and $1 \times 10^{-5}-1 \times 10^{-2} \mathrm{M}$ for $\mathrm{PO}_{4}^{3-}$.

\section{EXPERIMENTAL}

The FIA was carried out using a Nihonbunkou HPLC pump (880-PU), a spectrophotometer (870-UV) and an electrochemical detector (840-EC) [working electrode: glassy carbon $\left(0.16 \mathrm{~cm}^{2}\right)$; reference electrode: SCE; counter electrode: SUS-316] at room temperature. Stainless tubing $(0.25 \mathrm{~mm}$ i.d.) was used for the remainder of manifold. The manifold used is shown in Fig. 1.

Barium chloranilate and lanthanum chloranilate were obtained from Nacalai Tesque and Tokyo Kasei Kogyo, respectively. Hexacyanoferrate(III) was prepared by mixing $\mathrm{AgNO}_{3}$ and $\mathrm{K}_{3}\left[\mathrm{Fe}(\mathrm{CN})_{6}\right]$, and washed with water until the supernatant solution is free from silver ion. All other chemicals were of analytical-reagent grade.

A 100-300 mesh mixture of reacting reagents and matrix (cellulose or alumina) was fulfilled - - - - - - - - -

Department of Chemistry, Nagaoka University of Technology (Kamitomioka-machi 1603-1, Nagaoka, 940-21 Japan)

Key words; Displacement-Reaction Column, Flow Injection Analysis, Chloride, Sulfate, Phosphate

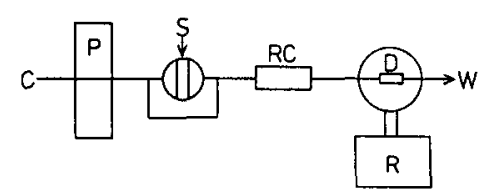

Fig. 1 Manifold of the FIA system with a displacementreaction column. $C$, carrier; $P$, pump; $S$, sample injection; $R C$, reaction column; $D$, detector ; $R$, recorder; $W$, waste.

into a HPLC stainless column ( $35 \mathrm{~mm} \times 4.6 \mathrm{~mm}$ i.d.). The column was washed by carrier solutions for $30 \mathrm{~min}$. Although a useful 1 ife-time depends on concentrations of samples, the column could be used for 50 or more injections without any change in response. The reaction efficiency was found to be $90 \%$ or more.

\section{RESULTS AND DISCUSSION}

\section{1 Chloride determination}

Although most flow injection procedures for $\mathrm{Cl}^{-}$determination employ $\mathrm{Hg}(\mathrm{SCN})_{2}$ and $\mathrm{Fe}(\mathrm{III})$ as reactants ${ }^{2)}, \mathrm{Ag}_{3}\left[\mathrm{Fe}(\mathrm{CN})_{6}\right]$ has been investigated as an alternative. Displacement reaction occurs between $\mathrm{Ag}_{3}\left[\mathrm{Fe}(\mathrm{CN})_{6}\right]$ and $\mathrm{Cl}^{-}$, the reaction being: $\mathrm{Ag}_{3}\left[\mathrm{Fe}(\mathrm{CN})_{8}\right]+3 \mathrm{Cl}^{-} \rightarrow$

$$
3 \mathrm{AgCl} \downarrow+\left[\mathrm{Fe}(\mathrm{CN})_{6}\right]^{3-}
$$

An equivalent amount of $\left[\mathrm{Fe}(\mathrm{CN})_{6}\right]^{3-}$ is 1 iberated, which is determined by electrochemical measurements or by spectrophotometrical ones.

Figure 2 shows an example of both the current (measured at $+0.2 \mathrm{~V}$ ) and the absorbance (measured at $436 \mathrm{~nm}$ ) calibration curves for $\mathrm{Cl}^{-}$determination. Samples as is concentrated were injected into the system without further dilution. In many cases, results for individual samples could be obtained within $40 \mathrm{~s}$ after injection. The proposed system could therefore perform routine replicate analyses at a speed of 150 or more samples/h. Well-established calibration graphs could be obtained for $0.1-25 \mathrm{w} / \mathrm{w} \% \mathrm{NaCl}$ (0.01-3.1M $\left.\mathrm{Cl}^{-}\right)$concentrations. The relative standard deviation for 10 replicate injections of $3 \% \mathrm{NaC} 1$ was 


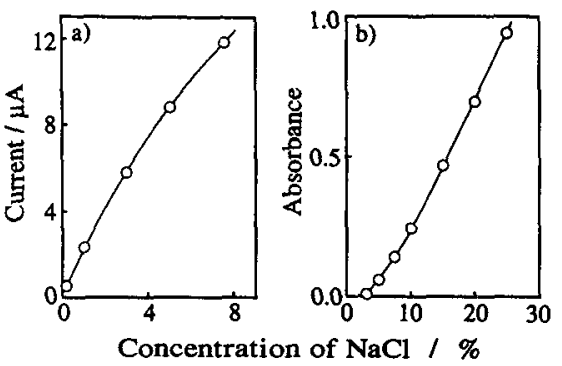

Fig. 2 Calibration curves for $\mathrm{NaCl}$. Camier, $0.05 \mathrm{M}$ $\mathrm{Ca}\left(\mathrm{NO}_{3}\right)_{2}$; flow rate, $3 \mathrm{ml} / \mathrm{min}$; injection volume, $1 \mu \mathrm{l}$.

ca. 2\%. Bromide and iodide ions interfered with the proposed method.

\subsection{Sulfate determination}

It is well known that solid $\mathrm{Ba}\left(\mathrm{C}_{6} \mathrm{Cl}_{2} \mathrm{O}_{4}\right)$, when added to $\mathrm{SO}_{4}{ }^{2-}$ solution, precipitates $\mathrm{BaSO}_{4}$ and releases an equivalent amount of $\mathrm{H}\left(\mathrm{C}_{6} \mathrm{Cl}_{2} \mathrm{O}_{4}\right)^{-}$, which exhibits absorbance maxima in the visible $(530 \mathrm{~nm})$ and ultraviolet regions $(330 \mathrm{~nm})^{3)}$.

$$
\begin{aligned}
& \mathrm{SO}_{4}{ }^{2-}+\mathrm{Ba}\left(\mathrm{C}_{6} \mathrm{Cl}_{2} \mathrm{O}_{4}\right)+\mathrm{H}^{+} \rightarrow \\
& \mathrm{BaSO}_{4} \downarrow+\mathrm{H}\left(\mathrm{C}_{6} \mathrm{Cl}_{2} \mathrm{O}_{4}\right){ }^{-}
\end{aligned}
$$

The reaction is dependent on $\mathrm{pH}$. Caribration curves were tested at various $\mathrm{pH}$ values using acetic acid (pH 3.27), acetate buffer (pH 4.20), borax buffer (pH 7.66) and boric acid(pH 9.01).

The results are shown in Fig. 3. The sensitivity decreased with increasing $\mathrm{pH}$. Although the highest sensitivity was obtained at $\mathrm{pH} 3.27$, the column life-time was rather short. Hence, $0.02 \mathrm{M}$ acetate buffer solution (pH 4.20) was selected as the carrier solution. Changing a flow rate(0.5-2 $\mathrm{ml} / \mathrm{min})$ and an injection volume $(5-50 \mu \ell) \mathrm{re}^{-}$ vealed that linear calibration curves could be obtained for $3-48000 \mathrm{pmm}(0.03-500 \mathrm{mM}) \mathrm{SO}_{4}{ }^{2-}$.

The present method was applied to the determination of $\mathrm{SO}_{4}{ }^{2-}$ in rain waters and in fresh concrete samples. The results obtained by this procedure were in good agreement with those by ion chromatography.

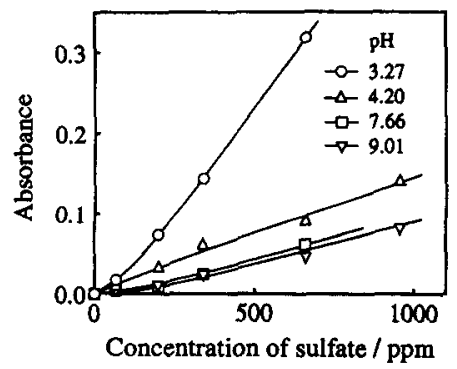

Fig. 3 Calibration curves for sulfate at various $\mathrm{pH}$. Flow rate, $1 \mathrm{ml} / \mathrm{min}$; injection volume, $20 \mu$ l.

\section{3 Phosphate determination}

$\mathrm{La}_{2}\left(\mathrm{C}_{6} \mathrm{Cl}_{2} \mathrm{O}_{4}\right)_{3}$ was used as a reaction reagent, the relevant reaction being: ${ }^{4)}$

$$
\begin{aligned}
& 2 \mathrm{PO}_{4}{ }^{3-}+ \mathrm{La}_{2}\left(\mathrm{C}_{6} \mathrm{Cl}_{2} \mathrm{O}_{4}\right)_{3}+3 \mathrm{H}^{+} \rightarrow \\
& 2 \mathrm{LaPO}_{4} \downarrow+3 \mathrm{H}\left(\mathrm{C}_{6} \mathrm{Cl}_{2} \mathrm{O}_{4}\right)^{-}
\end{aligned}
$$

Water-insoluble $\mathrm{LaPO}_{4}$ is precipitated and the $\mathrm{H}\left(\mathrm{C}_{6} \mathrm{Cl}_{2} \mathrm{O}_{4}\right)-1$ iberated is also proportional to the initial amount of $\mathrm{PO}_{4}{ }^{3-}$ in the sample.

A variety of carrier solutions were tested and $1 \mathrm{mM}$ ammonium succinate (pH 7) was selected. When the concentration of succinate was high, the solubility of $\mathrm{La}_{2}\left(\mathrm{C}_{6} \mathrm{Cl}_{2} \mathrm{O}_{4}\right)_{3}$ increased; a poor response was obtained. An example of recorder traces is shown in Fig. 4. It is possible to determine 1 - 300ppm (at $330 \mathrm{~nm}$ ) or $10-1000 \mathrm{ppm}$ (at $530 \mathrm{~nm}$ ) $\mathrm{PO}_{4}{ }^{3-}$ with an accuracy of $\pm 2 \%$ without interference from $\mathrm{Cl}^{-}$or $\mathrm{NO}_{3}{ }^{-}$up to $400 \mathrm{ppm}$.

Phosphate in cola was determined by both the present method and the conventional molybdenum blue method. The results, expressed in gram per liter, were 1.02 and 0.99 , respectively. Agreement between the two methods was excellent.

0 n the basis of the arguments presented above, the proposed FIA method is rapid and reliable. The principle of this method would have wide applicabilities in determining other anions.

We are grateful to the 4 th Tokyo Ohka Foundation for the Promotion of Science and Technology, for financial assistance.

\section{REFERENCES}

1) D. Chen, M. D. Luque de Castro and M. Valcarcel, Analyst, 116, 1095 (199l).

2) Ala'ddin M.Almuaibed and A.Townshend, Anal. Chim.Acta, 245, 115 (1991).

3) R. J.Bertolacini and J.E. Barney, Jr., Anal. Chem., 29, 281 (1957).

4) H. Hayashi, T.Danzuka and K.Ueno, Talanta, 4, $126(1960)$.

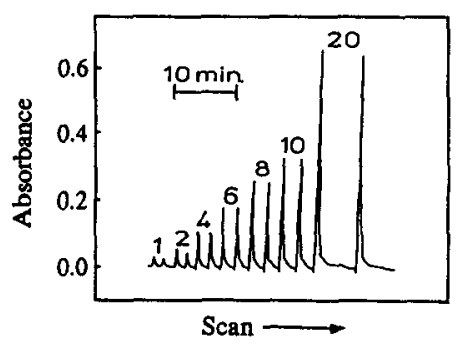

Fig. 4 Typical recorder traces for a 1-20ppm phosphate. Carrier, $1 \mathrm{mM}$ ammonium succinate: flow rate, $1 \mathrm{ml} / \mathrm{min}$; injection volume, $100 \mu \mathrm{l}$. 